\title{
The Needs for Official Sharia Compliance Audit Institution to Protect Customers of Islamic Banking: an Application through Hisba
}

\author{
Bharudin Che $\mathrm{Pa}^{1^{*}}$ \\ Sanusi Abdul Manaf2 \\ Mohd Roslan Mohd Nor ${ }^{3}$ \\ ${ }^{1}$ Department of Siasah Sharia, Academy of Islamic Studies, University of Malaya, \\ Kuala Lumpur, Malaysia \\ 2Student Development and Campus Lifestyle Division, Universiti Kuala Lumpur, \\ Kuala Lumpur, Malaysia \\ ${ }^{3}$ Department of Islamic History and Civilization, Academy of Islamic Studies, \\ University of Malaya, Kuala Lumpur, Malaysia \\ *Corresponding Author Email: bharudin@um.edu.my
}

\begin{abstract}
:
The emergence of Islamic banking system in most banks in Malaysia nowadays bring a new era in Malaysian banking industry. This article discusses the needs for official sharia compliance audit institution to protect customers of Islamic banking. By using literature studies, this article concludes that one of the contributing factors which lead people to adopt Islamic banking system is their awareness of the serious and intolerable prohibition of riba. Some of the ways to ensure customers are well protected are to establish hisba institution as Sharia compliance audit body. The establishment of hisba institution allows it to stop the violation of Allah's prohibition and protect the society. With the establishment of the institution, it can play an important role to solicit advice and to monitor performance so that the banks operate strictly as according to the Islamic regulations.
\end{abstract}

Keywords: Sharia audit, Islamic banking system, Customers, Hisba, Riba.

\section{A. INTRODUCTION}

According to Ernst \& Young in World Islamic Banking Competitiveness Report 2013-14, 38 million people have become customers of Islamic banking around the world (Ernst \& Young, 2013-14). This figure indicates that the industry has attracted the world community, and it is growing rapidly. In Malaysian context, Islamic banking industry recorded growth of 18.6\% from 2008 to 2012, whereas only $9.7 \%$ recorded by conventional banking industry for the same period (Kuwait Finance House, 2014:14). This rapid growth is influenced by the confidence that the community have in the system which is developed based on the Islamic principles.

However, there is a concern amidst the significant rapid growth of the industry, that is the standard of Sharia compliance will loosen, and as a result it will affect the customers' interests, besides other issues such as product disclosure and transparency, no directive from the authority to make it mandatory for Islamic banking institutions to undergo external audit, no government owned Sharia 
external audit institution and obscured qualification of external auditors who carry out Sharia audit. Thus, immediate measures need to be taken to keep the customers' interest. One of the measures is to apply hisba system concept in building an official audit body based on Sharia and owned by the government and a neutral body.

There is often a misconception about hisba as a body to monitor the operation in market places only. However, hisba is an Arabic term means incentive or reward is an institution that was early established in Islamic civilization history. The function of the institution is to enjoin what is right and to forbid what is wrong. In other words, it is related to the knowledge of Islamic management and administration which orientation is observation and monitoring so that the actions of the society or organisation are coherence with the demands of the sharia.

In organisational or institutional context, the area of duty seems to be limited to enjoining what is right and forbidding what is wrong. However, if it is scrutinised, it is holistic in nature which encompasses the organisational system and that includes the human capital operating that system. This means that the duty of hisba institution is not only to safeguard the system from any violations, but it is also to educate all levels of staff/employees in the organisation, the clients or anyone who are involved in the organisation.

\section{B. METHODS}

By using literature studies, in this paper, the author will focus on the introduction of hisba institution, how its role as an audit body to a finacial institution, how it carries out its duty to enjoin good and forbidding wrongdoings and the needs for hisba as sharia compliance audit body in Islamic banking system (Sharia Governance Framework, 2010: 25).

\section{RESULT AND DISCUSSIONS}

\section{The Concept of Hisba}

\section{a. The Concept of Hisba from Language Perspective}

From the language perspective, Sa'ad bin Abdullah bin Sa'ad al-'Arabi (1987:13) defined ḥisba as incentive or reward, which its noun is ihtisab that means hoping for reward from Allah Ta'ala.

\section{b. Terminological Perspective of Hisba}

Most writers provide almost similar explanation about the concept of hisba in Islam. Accroding to Dhiau al-Deen Muhammad bin Ahmad bin Abi Zaid (2001:13), "Hisba is enjoining good if it is obviously neglected and forbidding wrongdoings if there are people practicing it besides correcting each other. Saham Mustafa Abu Zaid (1986:43) said that hisba is the religious responsibility which foundation is to command for good behaviour and to forbid all wrongdoings. He further says that good behaviour or practice includes all conversation, action with the intention to comply with shara', but wrongdoings encompass all conversation, action, with the purpose to violate the shara'.

Similarly, the definition proposed by Subhi 'Abd al-Mun'im Muhammad (1993:16) which said that hisba commands for good practice when they are obviously neglected and forbids all wrongdoings if there are people doing it. Hence, as said by Sa'ad bin 'Abdullah bin Sa'ad (1987:21), it can be concluded that hisba is a religious responsibility which must be carried out as it is directly related to 
enjoining good especially when it is neglected and forbidding what is wrong that happens in the society. The concept is not only limited to economic administration, but it also encompasses every aspect of the Muslim society.

\section{c. Legitimacy of Hisisba In Islam}

The enforcement of hisba can be referred to Surah Ali 'Imran, verse 104,

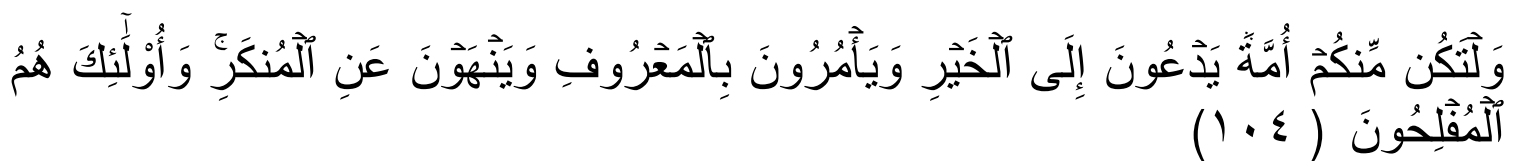

"Let there arise out of you a group of people inviting to all that is good (Islam), enjoining Al-Ma'ruf and forbidding Al-Munkar. And it is they who are the successful".

'Abdullah bin Ahmad bin Mahmud al-Nasafi (2001, l: 106) agreed with the opinion that the letter min (منكم) contained in minkum the ayat is li al-tab'îd (للتبعيض) which means the duty to call for good (al-ma'rüf) and to forbid wrongdoings (al-munkar) is the duty of scholars and not everyone is scholar. Thus, he opines that the responsibility is fard kifäya, which means it needs to be carried out by a certain group of people.

The same opinion was expressed by al-Qurtubi (1993, II: 194) who said that the duty to enjoin what is right and forbid what is wrong is fard kifāya which needs to be carried out by those who are knowledgable. He mentioned that the responsibility would not be accomplished according to Islam if it is not handled by those who know good (al-ma'rūf) and bad (al-munkar).

Similarly, the interpretation made by Muhammad 'Ali al-Sabuni (1996, I: 201) " the official duty of alamr bi al-ma'rūf wa al-nahy 'an al-munkar is not everyone's duty but it is the duty of a certain muslim group to carry out da'wa imposed by Allah that is to enjoin what is good and to forbid all wrongdoings".

Based on Wahbah al-Zuhaili (2001, I: 224) entrepretation, it is obligatory to all Muslims or a structured group of people or jamā'a to carry out the da'wah to enjoin good, to forbid wrongdoings, to protect the religion, to safeguard the rights, and to uphold justice.

On the other hand, the interpretation made by Sayyid Qutb (1982, I: 444) on the above verse is that there must be a group of people who carry out the duties to enjoin good and to forbid wrongdoings. He said that, the group of people must be those who are given the authority to carry out the da'wah.

In conclusion, it can be derived from the interpretations is that the responsibility to carry out al-amr bi al-ma'rūf wa al-nahy 'an al-munkar which is the pillar of hisba institution is fardh kifayah and not fard 'ayn (compulsory). Thus, those who are appointed to carry out hisba institution must be knowledgable and must fulfil the criteria outlined by Islam.

\section{d. The Qualification of Al-Muhtasib}

Hisba is a religious responsibility in which its role is to uphold the truth and forbid all wrongdoings in the society. This means that those who hold the responsibility must be trully qualified so that all the Islamic guidelines can be upheld. In this case, the fuqahā' have outlined several rules that must be 
adhered to by a muhtasib so that the actual meaning of hisba enforcement can be accomplished; that means materializing the sharia and ensuring the society welfare are guarded from those who have some personal interest (Abdullah, 1996: 137).

In the history of Islamic administration, those who carried out the responsibility or those who were appointed to take up the role is called al-muhtasib. Al-Muhtasib is a noun taken from the Arabic word hisba itself which means someone who is responsible to uphold good or ma'ruf and forbid wrongdoings or munkar in the Muslim society. In an appointment of an al-muhtasib, several conditions must be adhered to since it is a grand position in Islam.

According to Subhi 'Abd al-Mun'im Muhammad (1993: 39) also, some of the main conditions in the selection of an al-muhtasib are he must be mukallaf, believer, and capable of carrying out his duties. Thus, a person with mental disorder, not yet reach puberty or baligh, weak physically and kufr (nonbeliever) is not qualified at all to be al-muhtasib. In addition, an al-muhtasib who is to be appointed must also be a free citizen, just and have the knowledge to ascertain noticeable rights and wrongs. It is a must for an al-muhtasib to be a free citizen so that he can have the authority in carrying out his responsibility. An al-muhtasib must also be just and knowledgable in giving punishment to those who committed the forbidden acts.

Besides, an al-muhtasib must possess syakhsiyya or commendable personality (Zahir et.al., 1997: 100). The personality is very important to ensure an appointed al-muhtasib able to avoid himself from accepting bribery or using the public property wrongly. Moreover, Subhi 'Abd al-Mun'im Muhammad said that by having an excellent personality, he can be a role model to the society (1993:39).

Furthermore, 'Ali bin Muhammad bin Habib al-Mawardi al-Syafi'e (2002: 38) added that an almuhtasib must be among those who are well informed about his society. This condition is very important because all his efforts related al-amr bi al-ma'rūf wa al-nahy 'an al-munkar would not be successful if the al-muhtasib does not have the knowledge about his society. Being aware of the society social status, education, culture, tradition, economic status, wants and needs are the main factors for a lisbah institution success. For instance, being aware of the society condition will ease all the work in promoting al-amr bi al-ma'rūf wa al-nahy 'an al-munkar. Hence, it will ensure success of a hisba institution.

\section{e. The Role of Hisba Institution in Islam}

From the explanation above, it can be concluded that the role of hisba is to ensure the main shara' responsibility that is al-amr bi al-ma'rūf wa al-nahy 'an al-munkar can be implemented smoothly and effectively. When these two elements are carried out, the society will be able to live in peace and harmony. However, if there is no special organisation who is responsible to carry out this trust, the sharia will not be upheld accordingly.

In its special scope, it can be observed that hisba is very important in its responsibility to uphold alamr bi al-ma'rūf wa al-nahy 'an al-munkar. Firstly, the role of hisba is monitoring all wrongdoings that happened in business centres like marketplaces (Mawardi, 2002: 39). Hisba that is led by almuhtasib carries the responsibility to instruct those who are involved in business to be just in their business and also to stay away from wrongdoings in business such as ribā' and slandering. Meanwhile, monitoring activities must be done so that what is desired fulfills the religious demands. 
If any wrongdoing is detected, a strict action needs to be taken so that similar act will not be repeated, and it can be a lesson to other business operators.

The second role played by a hisba institution is to monitor all wrongdoings related to mu'amalat system in the society (Mawardi, 2002: 39). This includes every fasid business transaction companies, ribā' (interest) and other impermissible business dealings. The hisba institution as a government appointed body needs to put all efforts to ensure mu'āmala under its supervision does not violate the Islamic principles which forbid all kinds of oppression, deception and ribā'. If there is any violation of the system found, strict actions must be taken so that the society will feel secured.

The third role of hisba is its responsibility towards the citizens of kafir dhimmi or protected nonMuslim in Islamic state (Mawardi, 2002: 42). As a community living under the Islamic government, all their movements need to be monitored so that they would not trigger any wrongdoings that may tarnish Islam. Al-Muhtasib must make sure that among kafir dhimmi there are no wrongdoings such as killing the Muslims, committing adultery with the Muslims, defaming the Muslims, robbing and other bad actions that are against Islamic teaching. However, if they follow and obey the Islamic government, their welfare must be guarded and defended.

\section{f. The Needs for Hisba Institution in Islamic Banking System.}

It is very important to adopt the concept of hisba in administering a banking institution. Its significance can be observed when its implementation is seen as parallel with the sharia demands which concerns with the public wellbeing.

\section{g. To promote transparency}

Hisba institution is able to protect Islamic banking customers through its concern about transparency which needs to be upheld by every Islamic bank. In the context of Islamic banking operation, transparency entails that the Islamic banks should disclose to the customers any information that assist them to make quick and accurate assessments on financial conditions, achievements, business activities, risks profiles, and bank risk management practice (Ariffin et.al., 2009: 89-103).

Transparency practice is essential as it is the basis for depositors' confidence in all banking activities which include the enforcement of sharia principles such as prohibition of interest, the use of profit sharing, and other banking products. On the contrary, the unavailability of transparency will cause customers' inconfindence which will greatly affect the future of the bank.

In Islamic banking, transparency is very important because it strengthens the credibility and ethics of a sharia institution, besides, it increases customers' confidence and eradicates misunderstandings in all of their banking activities. Hence, the role of a sharia compliance audit body like hisba is necessary in ensuring the bank transparency and providing confidence to the society about Islamic banking system.

\section{h. To perform al-amr bi al-ma'rūf wa al-nahy 'an al-munkar in the organization}

One of the significance of hisba concept is al-amr bi al-ma'rūf wa al-nahy 'an al-munkar can be enforced in the organisation itself. In fact, the characteristic of hisba is that if any organisation is practicing the concept, the demand of al-amr bi al-ma'rüf wa al-nahy 'an al-munkar must be performed throughout all levels. The basic of al-amr bi al-ma'rūf wa al-nahy 'an al-munkar is indeed 
the universal foundation of Islam which is related to the main purpose of the Prophet (pbuh) being sent as the messenger, thus, Islamic principles can be upheld based on the concept ('Arifi, 1987: 15).

According to Abi Ya'la Muhammad bin al-Husin al-Farra' al-Hanbali, this indicates that, if good practice could be neglected, there must be a body to remind people to continue practicing it, and if there are wrongdoings or any practice that is against the shara', the practice must be stopped (Farra', 1983:284). Consequently, by having this kind of administration, an organisation will be shaped according to the mould of Islam and mașlaḥa of the society can be guarded.

\section{i. To perform holistic monitoring activities}

The adoption of hisba concept in an organisation will also ensure the organisation to have the quality demanded by Islam. This is because the monitoring process and examination conducted by almuhtasib is holistic which fulfils the three section of al-amr bi al-ma'ruf principles that is the rights of Allah, the rights of mankind and the rights related to both (Farra', 1983: 287).

He explained that, the meaning of Allah's rights is the performance of ibadah and responsibilities toward Allah. The rights of mankind are making sure all necessities required by them are fulfiled; meanwhile the rights of both parties are doing something that fulfils Allah demands and also the needs of other human beings (Farra', 1983: 287).

Similarly, the responsibility in performing al-nahyy 'an al-munkar is also divided into three categories which are the rights of Allah, the rights of mankind and the the rights of both (Farra', 1983: 291). In terms of Allah's rights in fulfiling the duty of al-nahyy 'an al-munkar, it means that all forms of almunkar whether they are in the aspects of ibadah, forbidden acts or mu'amalat, they must be obstructed from being practised by the society. For example, there is no additional rule in performing solah as it should be maintained according to the Prophet's teaching and if it happened, it must be obstructed because the practice is against Allah's rights (Farra', 1983: 292).

On the other hand, in relation to the violations of forbidden matters, it means people should be forbidden from following any dubious stance and avoiding applying punishment before any warning is given. For instance, when it is found that a man and a woman stopped at a public street, and there is no suspicious sign in them committing vice, thus, they will not be investigated. However, if they stopped at a quiet street and cause suspicion, they should be carefully investigated, but without hasty in applying punishment. This is because they may be mahram (Farra', 1983: 294).

Meanwhile, the meaning of forbidding al-munkar from the aspect of mu'amalat is getting involved in the business transaction that is fāsid in which it is deviated from the teaching of Islam (Farra', 1983: 296). This suggests that, by adopting the concept of hisba in administration, it can help the organisation to maximise its performance because all defects in the administration are monitored from all angles. Naturally, improvement process can be implemented after weaknesses are detected! Moreover, when the monitoring process is implemented in a comprehensive manner involving the staff and the system used, it displays the seriousness of an organization to uphold Islamic inspiration that seeks transparency in every aspect of its administration.

\section{j. To ensure that monitoring duty is discharged by qualified scholars}

According to 'Abdullah Muhammad 'Abdullah, the monitoring done by al-muhtasib is recognised by the religion of Islam because they are qualified in Sharia. Islam has prescribed a strict condition in 
carrying out the responsibility hisba by al-muhtasib which proves that the responsibility is very essential and indispensable in administration. Among the conditions to be al-muhtasib is al-taklif that are Muslim, bāligh (puberty) and sane. Other conditions include free, male, wise, has a firm stand in religious matters and has the mandate from the government to implement the duty of hisba ('Abdullah, 1996: 137).

\section{k. To gain high society confidence toward validity of an organisation's operation and its compliance with Sharia.}

The society will have the confidence with an organisation's operation if the organisation is operated based on the Islamic teaching. In the context of organisation that is guided by lisbah concept, the society would have high confidence toward the organisation for practising the principles of al-amr bi al-ma'rüf wa al-nahy 'an al-munkar is the practice that is based on the words of Allah S.W.T, as already mentioned (Surah Ali 'Imran: 104 ["Let there arise out of you a group of people inviting to all that is good (Islam) enjoining Al-Ma'ruf (i.e. Islamic Monothiesm and all that Islam orders one to do)and forbidding Al-Munkar (polythiesm and disbelief and all that Islam has forbidden). And it is they who are the successful]).

The practice of al-amr bi al-ma'rüf wa al-nahy 'an al-munkar is the main foundation in Islam and it becomes the main purpose of the message of the prophets. When the duty is neglected, deviation and ignorance in the society become widespsread which eventually leads to their destruction (Qasimi, 1929: 171).

Therefore, an organisation upholding this principle would develop confidence in the society who loves the good of the organisation. In addition, the staff/employees are also those who are trusted because they fulfil the criteria outlined by Islam. For instance, an employee who will carry out the duties of al-amr bi al-ma'rūf wa al-nahy 'an al-munkar must be an expert, just, firm in the religious matters, and knowledgeable about apparent evils or wrongdoings (Farra', 1983: 285).

\section{To promote comprehensively the Islamic teachings and be a role model for best practice in administration.}

'Abd al-Rahman Muhammad Badawi found that the adoption of hisba concept can also promote the Islamic teaching comprehensively and make it become an example for other organisations to take a step to practise it. Hisba in Islam which means enjoining the good and forbid the evil wrongdoings would be the most appropriate channel to obtain the reward from Allah through the administration monitoring activities (Badawi, 2006: 58).

The awareness in obtaining the reward and blessing from Allah through the monitoring activities would make an organisation become efficient, tranparent and responsible in its operation. Hence, it would be an example to other organisations to practice the concept of lisbah which adheres to the Islamic principles. Moreover, Islam does not only monitor wrongdoings but also provides the best solution according to syara'. Prevention in Islam is the real prevention that is it does not only investigate the wrongdoing but also tries to totally stop it from happening (Badawi, 2006:59). This attribute makes an organisation become continuously transparent and a role model to other organisations. 


\section{CONCLUSION}

It is obvious that hisba institution plays a vital role in establishing a sharia monitoring body which can protect the clients of Islamic banks from unfavourable and manipulating actions of the banks which may trigger the issues of transperancy and disclosure. Instead, the establishment of the body can uplift confidence and trust of the clients in the credibility and efficiency of the Islamic banks.

The model shows Sharia Auditing Process at four different levels. The process starts with all local Islamic banks and international Islamic banks audited by Sharia Department. Once they pass the audit at Sharia Department level, they will go through the Internal Audit Process. Then, the banks go through the External Audit Process, but this is optional. Finally, the banks undergo another audit by Sharia Compliance Audit Institution that is owned by the government, and this is a compulsory procedure for the banks to go through.

6DQXVL \%KDUKGGQ DQG 0 RKG 5RVQQ: SCAI MODEL:

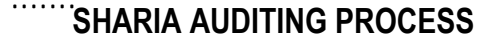

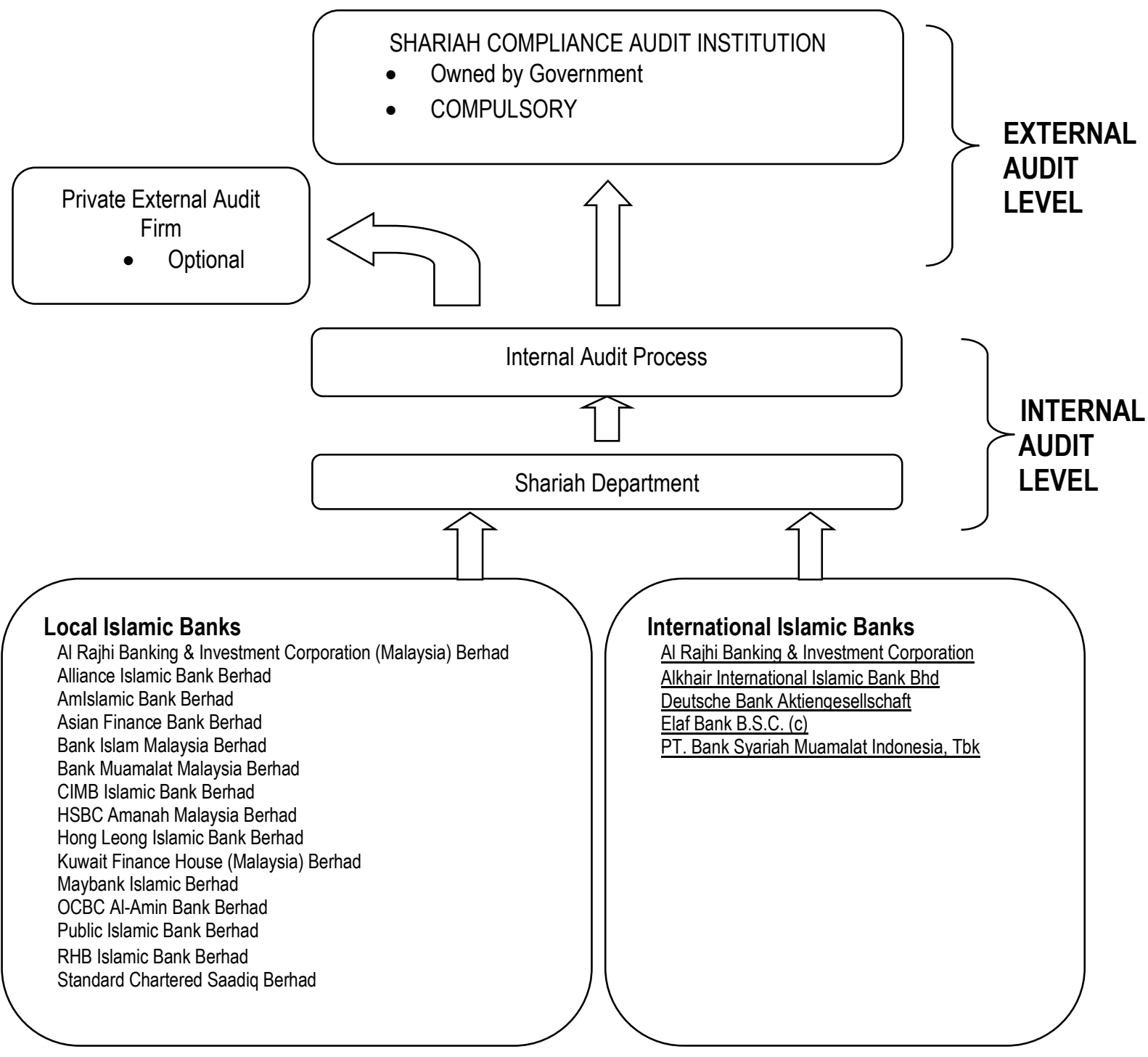




\section{References}

'Abdullah, 'Abdullah Muhammad. (1996). Wilāyat al-Ḥisba fĩ al-Islām, Kaherah: Maktabah al-Zahra'.

Abu Zaid, Saham Mustafa. (1986). Al-Hisbah fi Misr al-Islāmiyyah min al-Fath al-'Arabi ila Nihayah al-'Asr al-Mamluki, Kaherah.

al-'Arifi, Sa'ad bin 'Abdullah bin Sa'ad. (1987). Al-Hisba wa al-Niyābah al-'Amah-Dirasah Muqaranah, Riyadh: Dar al-Rusyd.

al-Farra', Abi Ya'la Muhammad bin al-Hussain al-Hanbali. (1983). Al-Aḥkām al-Sulțāniyyah, Beirut: Dar al-Kitab al-'Ilmiyyah.

Al-Mawardi, 'Ali bin Muhammad bin Habib al-Syafi'i. (2002). Al-Ruțbah fi Ṭalab al-Ḥisba, AlQaherah: Dar al-Risalah.

al-Nasafi, 'Abdullah bin Ahmad bin Mahmud. (2001). Tafsīr al-Nasāi: Al-Musamma Madārik al-Tanzīl wa Haqāiq al-Ta'wīl, Beirut: Dar al-Kitab al-'Ilmiyyah.

al-Qasimi, Muhammad Jamil al-Deen al-Dimasyqi. (1929). Mau'izah al-Mu'minīn min Ihyā'’ 'Ulūm alDin, Mesir: Dar al-Husul wa al-Nasyr.

al-Qurtubi, Abi 'Abdullah Muhammad bin Ahmad al-Ansari. (1993). Al-Jāmi' al-Aḥkām al-Qurānn, Beirut: Dar al-Kitab al-'Ilmiyyah.

al-Sabuni, Muhammad 'Ali. (1996). Safwah al-Tafāsir: Tafsīr li al-Qur'ān al-Karīm, Beirut: Dar alFikr.

al-Zuhaili, Wahbah. (2001). Al-Tafsìr al-Wasiț, Beirut: Dar al-Fikr al-Mu'asir.

Ariffin, Noraini Mohd.; Archer, Simon \& Karim, Rifaat Ahmed Abdel. (2009). Issues of Transparency in Islamic Banks, Journal of Review of Islamic Economics, Vol. 13, No. 1, pp. 89-103

Badawi, 'Abd al-Rahman Muhammad. (2006). Al-Islām wa al-Raqabah al-Māliyah al-Mu'asarah, Dar al-Ahmadi li al-Nasyr.

Bank Negara Malaysia. (2011). Sharia Governance Framework 2010. Retrieved Disember 9, 2011, from http://www.bnm.gov.my/guidelines/05_sharia/02_Sharia_Governance_Framework_2 0101026.pdf

Dhiau al-Din, Muhammad bin Ahmad bin Abi Zaid. (2001). Ma'ālim al-Qurbah fi Ahkām al-Ḥisbah, Beirut: Dar al-Kitab al-'Imiah.

Ernst \& Young. (2013). World Islamic Banking Competitiveness Report (http://www.ey.com/Publication/vwLUAssets/EY_World_Islamic_Banking_Competitivenes S_Report_2013\%E2\%80\%9314/\$FILE/EY-World-Islamic-Banking-CompetitivenessReport-2013-14.pdf). 
Khalid Khalil al-Zahir \& Hussein Mustafa Tabarah. (1997). Nizāām al-Hisbah : Dirāsah fĩ al-Idārah allqtișādiyyah li al-Mujtama' al-'Arabī al-Islāmī, Amman: Dar al-Masirah.

Kuwait Finance House. (2014). Islamic Finance Outlook 2014, Kuala Lumpur: KFH Research Ltd.

Muhammad, Subhi 'Abd al-Mun'im. (1993). Al-Hisbah fĩ al-Islām: Bayn al-Nazariyyah wa al-Tațbīq, Mesr: Dar al-Riyadh al-Salihin.

Qutb, Sayyid. (1982). Fī żilāl al-Qur'ān, Beirut: Dar al-Syuruq.

Sharia Governance Framework. (2010). http://www.bnm.gov.my/guidelines/05_sharia/02_ Sharia_Governance_Framework_20101026.pdf). 